\title{
Kinetic analysis of the metatarsophalangeal joint in normal subjects and hallux valgus patients during walking using a four-segment foot model
}

Bora Jeong, Seunghyeon Kim, Jongsang Son, Youngho Kim

From 4th Congress of the International Foot and Ankle Biomechanics (i-FAB) Community

Busan, Korea. 8-11 April 2014

The foot plays an important role in human walking [1]. The foot has many essential functions such as shock absorption, weight bearing stability and push-off. The metatarsophalangeal (MP) joint, positioned between the metatarsal bones of the foot and the proximal phalanges of the toes, provides a broad area of support across the forefoot. The major role of the MP joint is the energy absorption during the terminal stance of the gait cycle [2].

Hallux valgus (HV), the most common great toe disorder, is a deformity of the first MP joint [3]. In HV patients, the mechanical role of the MP joint might change to compensate for the worsening of the loading condition, decreased weight-bearing function of the medial toe, and weight transfer to the lateral metatarsals [4-7]. Some researchers have investigated kinematics of the MP joint $[8,9]$. However, there was rare investigation of the MP joint kinetics. In this study, kinetics of the MP joint was determined during the entire stance period of the gait cycle using a four-segment foot model.

The three-dimensional motion analysis was used with foot pressure measurement. Twelve normal subjects and ten HV patients were selected for this study.

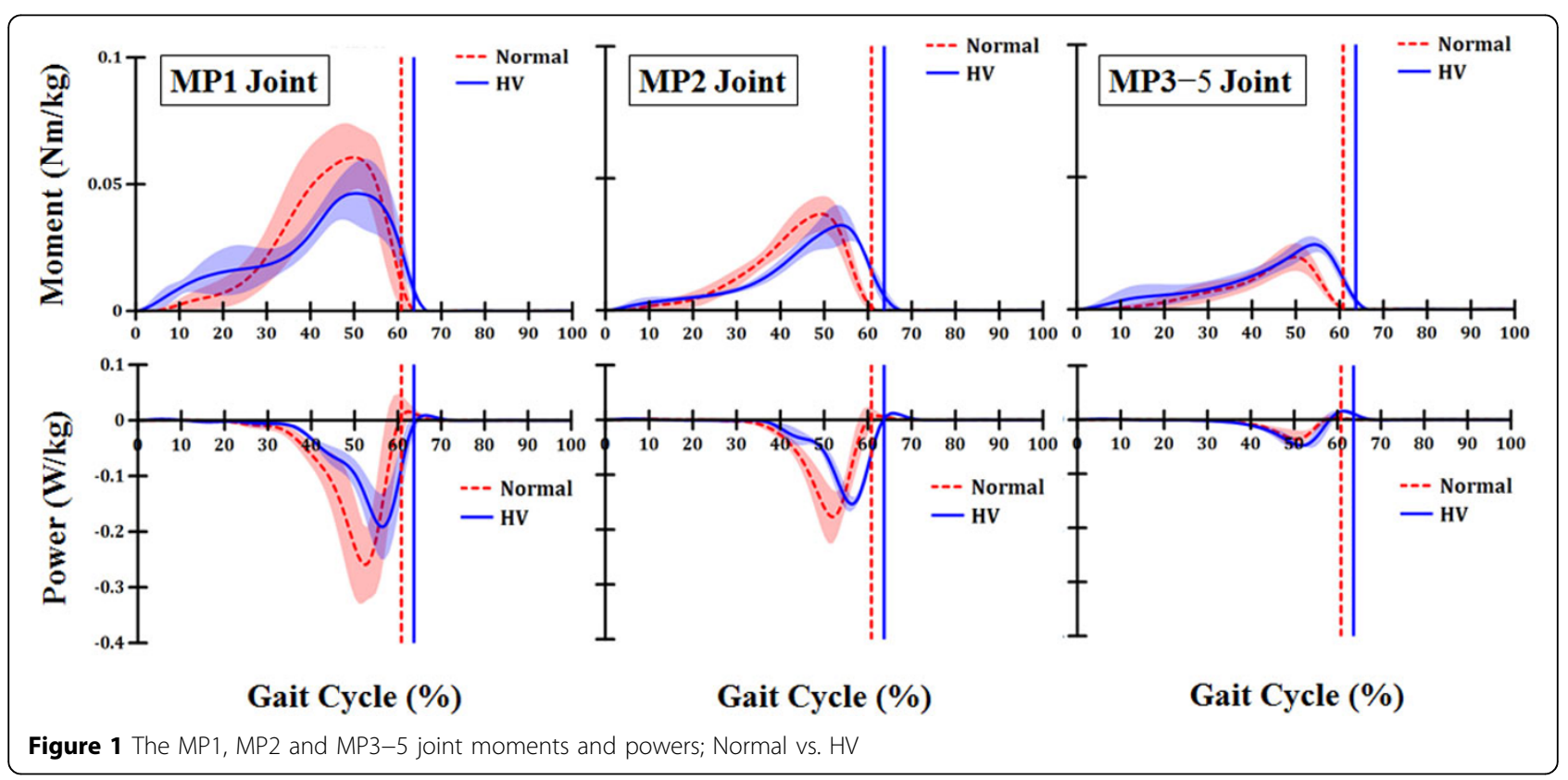

\footnotetext{
* Correspondence: younghokim@yonsei.ac.kr Yonsei University, Wonju, Gangwon, 220-710, Korea
} 
Results showed that a significant difference in stance time was found between the normal $(60.86 \pm 1.21 \%)$ and HV groups $(63.75 \pm 0.91 \%)(p<0.05)$. The ankle joint moment for the normal group and the HV group was not significantly different. However, the peak MP1 moment in the HV group was significantly smaller than in the normal group $(p<0.05)$. Considerable energy absorption was observed from the terminal stance to pre-swing in both groups. However, total energy absorption in all MP joints decreased $25 \%$ in the HV group $(4.59 \pm 0.85 \mathrm{~J} / \mathrm{kg})$ compared with the normal group $(6.09 \pm 1.00 \mathrm{~J} / \mathrm{kg})$. The energy absorption in the MP1 joint and the MP2 joint were significantly smaller in the HV group than in the normal group $(p<0.05)$. However, no significant difference in energy absorption for the MP3-5 joint was observed between the normal group and the HV group $(p>0.05)$.

This study had some limitation such as assumption that the MP3-5 joints act as a single joint and small number of the HV patients. In spite of those limitations, our study would be helpful in understanding the mechanical role of the MP joint in patients with foot disease.

\section{Acknowledgement}

This research was supported by the Human Resource Training Project for Regional Innovation through the National Research Foundation of Korea (NRF) funded by the Ministry of Education (2013H1B8A2032194).

Published: 8 April 2014

\section{References}

1. Boonpratatong $A$, Ren $L:$ The human ankle-foot complex as a multiconfigurable mechanism during the stance phase of walking. Journal of Bionics Engineering 2010, 7:211-218.

2. Miyazaki S, Yamamoto S: Moment acting at the metatarsophalangeal joints during normal barefoot level walking. Gait \& Posture 1993, 1:133-140.

3. Plank MJ: The pattern of forefoot pressure distribution in hallux valgus. The foot 1995, 5:8-14

4. Deschamps K, Birch I, Desloovere K, Matricali GA: The impact of hallux valgus on foot kinematics: A cross sectional, comparative study. Gait \& Posture 2010, 32:102-106.

5. Yavuz M, Botek G, Davis BL: Plantar shear stress distributions: comparing actual and predicted frictional forces at the foot-ground interface. Journal of Biomechanics 2007, 40:3045-3049.

6. Blomgren M, Turan I, Agadir M: Gait analysis in hallux valgus. Journal of Foot Surgery 1991, 30:70-71.

7. Hutton WC, Dhanendran M: The mechanics of normal and hallux valgus feet - a quantitative study. Clinical Orthopaedics and Related Research 1981, 157:7-13.

8. Kernozek TW, Elfessi A, Sterriker S: Clinical and biomechanical risk factors of patients diagnosed with hallux valgus. Journal of the American Podiatric Medical Association 2003, 93:97-103.

9. Mickle KJ, Munro BJ, Lord SR, Menz HB, Steele JR: Gait, balance and plantar pressures in older people with toe deformities. Gait \& Posture 2011, 34:347-351.

\section{doi:10.1186/1757-1146-7-S1-A125}

Cite this article as: Jeong et al: Kinetic analysis of the

metatarsophalangeal joint in normal subjects and hallux valgus patients during walking using a four-segment foot model. Journal of Foot and Ankle Research 2014 7(Suppl 1):A125.

\section{Submit your next manuscript to BioMed Central and take full advantage of:}

- Convenient online submission

- Thorough peer review

- No space constraints or color figure charges

- Immediate publication on acceptance

- Inclusion in PubMed, CAS, Scopus and Google Scholar

- Research which is freely available for redistribution 